\title{
A Case of Endoscopic Repair of Cerebrospinal Fluid Rhinorrhea Associated with Primary Empty Sella Syndrome
}

\author{
Jun Hyuk Chi, Seok-Won Park, Min Seok Han and Eun Kyeong Lee \\ Department of Otorhinolaryngology-Head and Neck Surgery, Dongguk University College of Medicine, Ilsan Hospital, Goyang, Korea
}

\section{원발성 빈 안장 증후군에 동반한 뇌척수액 비루의 내시경적 치험 1 예}

지준혁 · 박석원 · 한민석 · 이은경

동국대학교 의과대학 일산병원 이비인후-두경부외과학교실

\author{
Received July 1,2011 \\ Revised August 4, 2011 \\ Accepted August 6, 2011 \\ Address for correspondence \\ Seok-Won Park, MD, PhD \\ Department of Otorhinolaryngology- \\ Head and Neck Surgery, \\ Dongguk University \\ College of Medicine, \\ Ilsan Hospital, 814 Siksa-dong, \\ Ilsandong-gu, Goyang 410-773, \\ Korea \\ Tel $+82-31-961-7430$ \\ Fax $+82-31-961-7427$ \\ E-mailsw43857@dumc.or.kr
}

The empty sella syndrome is defined as the herniation of a subarachnoid space within the sella, with a flat-pressed pituitary gland accompanying hormonal problems or cerebrospinal fluid (CSF) rhinorrhea. CSF rhinorrhea is rare in the primary empty sella syndrome. We report a case of primary empty sella syndrome with CSF rhinorrhea in a 57 year-old woman. The CSF rhinorrhea was treated successfully by endoscopic transnasal transsphenoidal approach. Korean J Otorhinolaryngol-Head Neck Surg 2011;54:727-30

Key Words Empty sella syndrome · Cerebrospinal fluid rhinorrhea · Endoscopic surgery.

\section{서 론}

빈 안장(empty sella) 또는 공터어키안이라는 용어는 1951년 von W. Busch에 의해 처음 기술된 용어로서, 불완전한 안부 격벽(diaphragm sellae)을 통하여 지주막하강(subarachnoid space)이 결손부위를 통하여 안장내로 확장되어 뇌하수체가 뇌하수체 오목(pituitary fossa)의 후하방에 납작하게 눌려 있는 상태를 지칭한다. ${ }^{1-4)}$ 뇌하수체의 병변에 대해 수술이나 방사선 치료를 한 후에 뇌하수체가 위축되어 속발하는 경우 를 이차성(secondary) 빈 안장, 그렇지 않은 경우를 일차성(primary) 빈 안장으로 구분한다. 선천성 안부격벽 결손은 일차성 빈 안장에 속한다. ${ }^{1,2)}$ 빈 안장 증후군(empty sella syndrome) 은 빈 안장에 동반하여 뇌하수체 호르몬과 관련된 내분비계 의 이상이나 두개내압의 증가로 인한 증상이 있거나 뇌척수
액 유출 등의 관련증상이 있는 경우를 지칭한다.

국내에서 뇌척수액 비루를 보이는 빈 안장 증후군 증례는 3예가 보고되었으나 내시경 수술로 치료된 보고는 없다. ${ }^{5-7)}$ 저 자들은 뇌척수액 비루를 보이는 일차성 빈 안장 증후군 환자 를 비중격을 경유하지 않는 내시경적 경비 접형동 접근법(endoscopic transnasal transsphenoidal approach)으로 치유 한 1 예를 경험하였기에 문헌 고찰과 함께 보고하는 바이다.

\section{증 겨}

57세 여자가 내원 당일 발생한 두통, 구토 및 의식 명료도 의 저하(drowsiness)를 주소로 본원 응급실에 내원하였다. 환자는 내원 2주 전부터 상기도 감염 증세가 있었다고 하였 다. 환자의 활력징후는 안정적이었으나 경부 강직이 있어 수 
막염을 의심하였다. 요추천자시 탁한 뇌척수액이 배액되었고 뇌척수압은 $29 \mathrm{~cm} \mathrm{H}_{2} \mathrm{O}$ 였다. 뇌척수액검사상 백혈구 수는 $7,200 / \mathrm{uL}$ 이었으며 호중구 $100 \%$, 단백 $597 \mathrm{mg} / \mathrm{gL}$ 이었고, 연 쇄상구균 항원 양성으로 연쇄상 구균에 의한 수막염으로 진 단되었다. 환자는 즉시 신경과 중환자실에 입원하여 ceftriaxone을 포함한 약물치료를 시작하였다.

입원 3일째 시행한 자기공명영상(magnetic resonance image, MRI)에서 수막염에 합당한 미만성 연수막 조영증강 소 견(diffuse leptomeningeal enhancement)을 보였고, 그 외에 도 빈 안장 소견과 우측 접형동에는 점막의 비후와 조영증강 이 되지 않는 액체저류의 신호강도를 보였다(Fig. 1).

환자는 의식이 호전되면서 주로 기상시 발생하는 수양성 비루를 호소하기 시작하였다. 비루의 당 농도는 $87 \mathrm{mg} / \mathrm{dL}$ 로 뇌척수액 비루임이 의심되었다. 입원 9일째 방사성 동위원소 뇌수조조영술(99mTc-DTPA RI cisternography)에서 우측 접형동의 방사능 축적이 보여 뇌척수액 유출이 있음을 알 수 있었다. 환자는 뇌척수액 비루를 동반하는 일차성 빈 안장 증후군으로 진단이 내려진 상태에서 입원 10 일째 이비인후 과에 의뢰되었으나 비내시경검사로는 이상 소견을 발견하지 못하였다. 수술 전 시행한 전산화단층촬영에서는 우측 접형동 내의 점막비후와 기수면(air-fluid level) 등 자기공명영상과 유사한 소견이 관찰되었으나 뚜렷한 골벽의 결손부위는 확 인되지 않았다(Fig. 2). 재차 시행한 뇌척수액 검사에서는 뇌 척수압이 $15 \mathrm{cmH}_{2} \mathrm{O}$ 였으며 뇌막염의 소견은 보이지 않았다.

입원 15 일째 내시경적 경비 접형동 접근법을 이용하여 내시

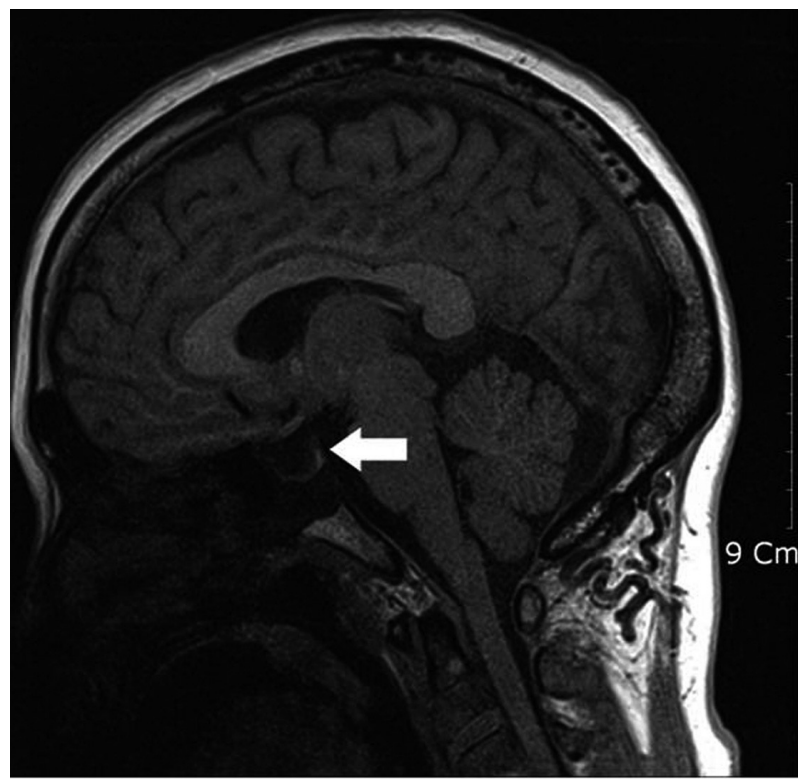

Fig. 1. Preoperative sagittal T1-weighted MR image demonstrating enlarged sella turcica, filled with cerebrospinal fluid (white arrow). MR: magnetic resonance.
경 시야하에 뇌척수액 유출을 막는 수술을 시행하였다. 수술 전 요추 천자를 시행하였고, 뇌척수액 $10 \mathrm{cc}$ 를 채취하여 $10 \%$ fluorescein $0.25 \mathrm{cc}$ 를 섞은 뒤 천자부위로 다시 주입하였다. 전신마취하 내시경을 이용하여 우측 접형동 자연공 확장술 을 시행한 후 접형동 내를 관찰하였으나 점막이 전반적으로 비후되어 있어 유출부위를 확인하기 어려웠다. 접형동의 점

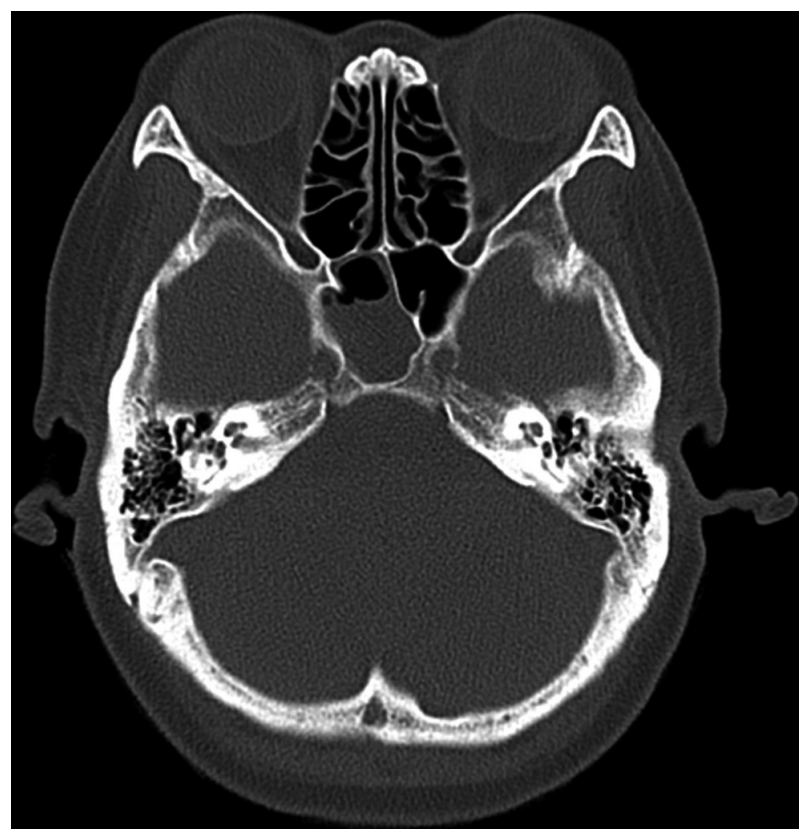

Fig. 2. Preoperative axial CT scan image demonstrating presence of air-fluid level and mucosal thickening in sphenoid sinus. CT: computed tomography.

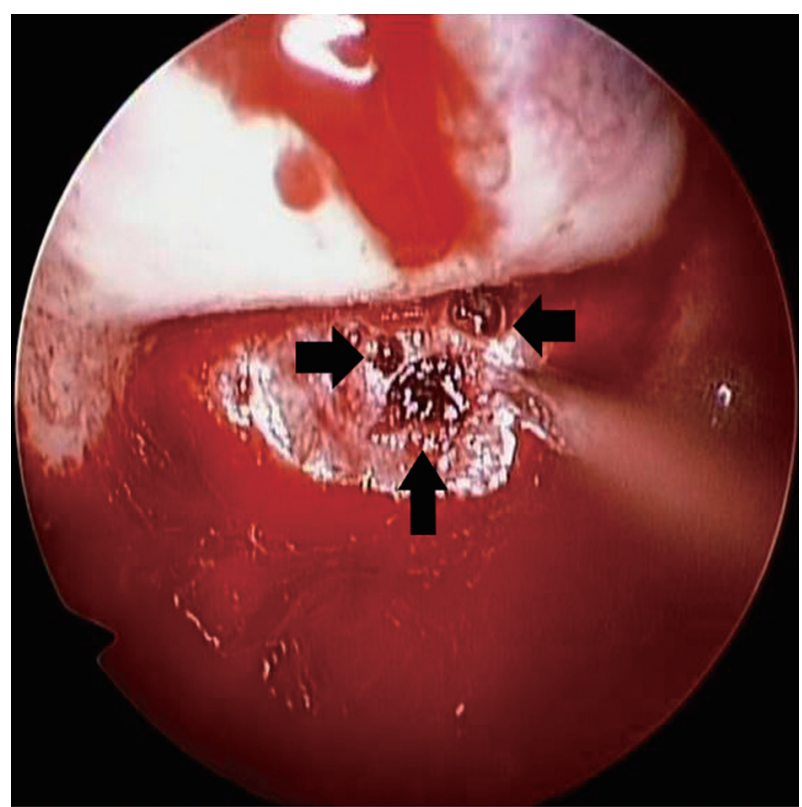

Fig. 3. Operative finding demonstrating three defect sites (black arrows) at clivus in the sphenoid sinus which were blocked with pieces of oxidized cellulose. 
막을 완전히 제거하고 난 후, 안장 직하부의 사대(clivus)에 해당하는 접형동 후벽에서 $2.5 \mathrm{~mm}$ 크기의 골 결손부위 및 주변에 $2 \mathrm{~mm}$ 보다 작은 크기의 골 결손부위 두 곳 등 경막 외로 서로 교통하는 세 군데의 골 결손부위가 발견되었고 결 손부위를 통하여 염료로 착색된 뇌척수액의 유출이 확인되 었다(Fig. 3). Oxidized cellulose(Surgicel ${ }^{\circledR}$ ) 조각을 골 결손 부위에 단단히 넣고 측두근막을 이용하여 결손부위를 막은 뒤 섬유교(fibrin glue)를 뿌린 후 복부에서 채취한 지방 조 직을 접형동 내에 충전하였다. 접형동 자연공 부위는 중비갑 개에서 채취한 골편을 넣어서 막은 뒤 비강에 패킹을 채우고 수술을 종료하였다.

환자는 수술 후 5 일째에 요추 배액관과 패킹을 제거하였다. 골편은 치료 도중 탈락되었으나 나머지의 이식물들은 잘 생 존하였으며, 환자는 수술 후 34일째에 후유증 없이 퇴원하였 다. 환자는 퇴원 이후 3 년째 비루나 뇌막염의 재발 없이 추적 관찰 중이다.

\section{고 찰}

빈 안장은 안부격벽의 결손에 의해서 발생하는데, 두개내 압의 상승이나, 뇌하수체 부피의 감소에 의해서도 발생하지만 특별한 이유없이 정상 변이에 의해서 발생하여 우연히 발견되 는 경우가 대부분이다. ${ }^{8)}$ 빈 안장은 부검 연구에서 5.5 23\% 에서 발견되었다고 하며, 최근에는 computed tomography (CT)와 MRI가 널리 이용되면서 우연히 발견되는 경우가 증 가하였다. ${ }^{2,3}$ 또한 빈 안장을 가진 환자 중 20 50\%가 내분비 계의 이상을 동반하며, 이중 5\%의 환자에서는 부분 뇌하수 체 저하증, $25 \%$ 의 환자에서는 전 뇌하수체 저하증, 그리고 $10 \%$ 의 환자에서는 고프로락틴혈증을 나타낸다고 보고되었 다. ${ }^{2}$ 빈 안장 증후군은 여성에서 좀 더 흔하다고 보고되었으 나, 최근 보고에 의하면 성별의 차이는 없다고 한다.) 비만, 고 혈압, 두통 및 시력 변화와 동반되는 경우가 많다고 하며, 드물 게 뇌척수액 비루와 유두부종을 동반하는 경우도 있다. ${ }^{3)}$ 본 증례에서는 수양성 비루 외에 다른 증상은 관찰되지 않았으 며 내분비계 이상도 발견되지 않았다.

뇌척수액 비루의 경우, 일차성과 이차성으로 구분할 수 있 으며 $80 \%$ 이상이 두부 외상과 관련된 이차성 뇌척수액 비루 이다. 일차성 뇌척수액 비루는 비교적 드문 질환으로 전체 뇌 척수액 비루의 3 4\% 정도를 차지한다. 일차성 뇌척수액 비루 의 위험 인자는 빈 안장 증후군, 두개기저기형과 비만에 의한 두개내압의 증가이다.9) 빈 안장 증후군에서 뇌척수액 비루가 발생하는 빈도는 드문것으로 보여지며, 213명의 일차성 빈 안 장 증후군의 환자 중 14 명의 환자에서 뇌척수액 비루가 있었
다는 보고도 있다. ${ }^{10}$

뇌척수액 비루 여부의 진단은 의심되는 비루에서 당을 측 정하거나 $(30 \mathrm{mg} / \mathrm{dL}$ 이상시 의심), $\beta 2$-transferrin 등을 전기 면역영동을 통해 확인하는 방법 등이 필요하다. 뇌척수액 유 출 부위의 진단에는 이온 조영제를 이용한 전산화단층촬영 뇌조조영술 등이 이용된다. 최근에는 방사선 동위원소를 이용 한 뇌조조영술이 행해지고 있다. ${ }^{11)}$ 경막하 fluorescein 주입은 전산화단층촬영에서 결손 부위를 찾지 못하였을 때 유용하 게 사용할 수 있고, fluorescein으로 착색된 뇌척수액 누출 을 관찰함으로써 유출 부위를 관찰할 수 있다. 경막하 fluorescein 주입의 합병증으로는 드물고 대부분 가역적으로 경 련이나, 하지 쇠약을 유발할 수 있다. ${ }^{12)}$ 빈 안장에서 두개기저 의 결손을 통해 뇌척수액 비루가 발생할 수 있는데 전두동, 접형동, 사골동을 통해 뇌척수액의 누출이 일어날 수 있다. 뇌 척수액의 가장 흔한 부위는 접형동의 가쪽 오목이었으며, 이어 서 접형동의 중앙 부위, 사골동의 천정과 사상판 등의 순이 었다. ${ }^{6}$ 그러므로, 빈 안장에서 뇌척수액 비루가 있을 때는 앞 에서 기술한 여러가지 검사를 통해 누출 부위를 사전에 확실 하게 확인하는 것이 중요하다.

이차성 빈 안장 증후군에서 뇌척수압 상승이 있지만 시력 소실이 관찰되지 않을 때는 약물로 치료할 수 있지만, 유두 부종, 심한 두통, 시력의 변화 등의 신경학적인 증후나 뇌척 수액 비루가 있으면 수술적 치료가 필요하다. ${ }^{10)}$ 전통적으로는 경전두동 접근법을 통한 수술적 치료를 이용하였으나 최근 에는 이러한 일차성 뇌척수액 비루가 있을 때 비강을 통한 내 시경적 접근법으로 뇌척수액 유출 부위의 교정 성공률이 $90 \%$ 이상으로 보고되고 있다.13)

빈 안장에 동반되는 뇌척수액 비루는 뇌척수압 증가를 동 반하는 경우가 많은데, 본 증례의 경우에서도 뇌척수액 압력 은 $29 \mathrm{cmH}_{2} \mathrm{O}$ 로 정상 $\left(0 \sim 15 \mathrm{cmH}_{2} \mathrm{O}\right)$ 에 비해 상승되어 있었 다. 하지만 빈 안장이 있는 상태에서 수막염이 발생하였고, 비루의 병력이 없던 환자에서 수막염 발생 후 비루가 발생하 였다가 수막염이 호전되면서 다시 비루가 감소하여 없어지는 증상을 보이면서 내시경으로 골 결손부위가 다수 관찰되었 다. 이로 미루어보아 다음과 같은 병태생리를 추정할 수 있 다. 이 증례에서 선행되었던 상기도 감염이 접형동 점막에 영 향을 주었고 이는 골 결손을 통해 수막염을 유발하였고 뇌 막염이 발생하면서 뇌척수압의 증가를 유발하여 빈 안장으 로 뇌척수압이 안장의 저부에 직접 전달이 되면서 저부 주변 의 골벽이 얇아져 결손이 생긴 것으로 추정할 수 있다. 결손 부위를 통한 뇌척수액 비루가 발생하였고 수막염이 치유되 면서 뇌척수압이 감소하고 이로 인해 결손부위가 자연적으 로 치유되어 비루가 감소한 것으로 추정된다. 하지만 골 결손 
이 여전히 있고 빈 안장이라는 선행 상황이 그대로 있으므로 향후 비슷한 상황에서 재발의 위험성이 높다. 따라서 유출부 위 주변의 골부를 노출시킨 후 새 점막을 이식시켜 잘 덮이 게 하는 일반적인 내시경적인 뇌척수액 유출의 치료방법으 로 충전을 하여 접형동을 폐쇄하여 재발의 가능성을 원천적 으로 봉쇄하는 것이 빈 안장 증후군에서의 뇌척수액 비루에 대한 정확한 치료라고 본다. 경비중격 접형동 접근법은 뇌척 수액 비루를 동반한 원발성 빈 안장 증후군 환자에서 골 결 손을 막는 좋은 치료법이지만 비중격을 희생하여야 하는 단 점이 있다. 저자들은 내시경적 경비 접형동 접근법을 이용하 여 성공적인 결과를 얻었다.

\section{REFERENCES}

1) Kim JH, Ko JH, Kim HW, Ha HG, Jung CK. Analysis of empty sella secondary to the brain tumors. J Korean Neurosurg Soc 2009;46(4): 355-9.

2) Komada H, Yamamoto M, Okubo S, Nagai K, Iida K, Nakamura T, et al. A case of hypothalamic panhypopituitarism with empty sella syndrome: case report and review of the literature. Endocr J 2009;56 (4):585-9.

3) Del Monte P, Foppiani L, Cafferata C, Marugo A, Bernasconi D. Primary "empty sella" in adults: endocrine findings. Endocr J 2006;
53(6):803-9.

4) Luutu I. Empty sella syndrome: incidental findings at computerised tomography. Afr Health Sci 2001;1(1):26-7.

5) Kim BG, Nam SK, Cho SM. A case of cerebrospinal fluid rhinorrhea with bony defects on both sides of the cribriform plate associated with primary empty sella. Diagnosis and Treatment 2009;29(5):511-7.

6) Chang YC, Jung HW, Yang HS, Kim CG. A case of cerebrospinal fluid rhinorrhea associated with primary empty sella syndrome. Korean J Otolaryngol-Head Neck Surg 1999;42(7):916-8.

7) Choi JC, Kim JY, Park BG, In SM. A case of empty sella syndrome with cerebrospinal fluid rhinorrhea. Korean J Otolaryngol-Head Neck Surg 2006;49(2):216-20.

8) Sage MR, Blumbergs PC. Primary empty sella turcica: a radiological-anatomical correlation. Australas Radiol 2000;44(3):341-8.

9) De Marinis L, Bonadonna S, Bianchi A, Maira G, Giustina A. Primary empty sella. J Clin Endocrinol Metab 2005;90(9):5471-7.

10) Lopatin AS, Kapitanov DN, Potapov AA. Endonasal endoscopic repair of spontaneous cerebrospinal fluid leaks. Arch Otolaryngol Head Neck Surg 2003;129(8):859-63.

11) Bae SH, Kim HD, Lee JK, Lim SC. Management of cerebrospinal fluid rhinorrhea. Korean J Otolaryngol-Head Neck Surg 2004:47 (12):1241-6

12) Bateman N, Mason J, Jones NS. Use of fluorescein for detecting cerebrospinal fluid rhinorrhoea: a safe technique for intrathecal injection. ORL J Otorhinolaryngol Relat Spec 1999;61(3):131-2.

13) Woodworth BA, Palmer JN. Spontaneous cerebrospinal fluid leaks. Curr Opin Otolaryngol Head Neck Surg 2009;17(1):59-65. 